\title{
Identifying Constraints and Opportunities for Improving the Health and Productivity Of Chickens Raised By Smallholder Farmers In The Marginal Upland Barangays Of Inopacan, Leyte, Philippines
}

\author{
Eugene B. Lañada and Dave D. Amihan \\ Department of Veterinary Paraclinical Sciences, College of Veterinary Medicine, \\ Visayas State University, Baybay City, Leyte, 6521-A
}

\section{ABSTRACT}

To identify constraints and opportunities for improving the health and productivity of chickens raised by smallholder farmers in the marginal uplands, a survey was carried out in 4 upland barangays of Inopacan, Leyte, involving questionnaire-interviews on smallholder chicken raisers. Data were gathered from randomly selected households during a single visit to each of these households using a structured data collection sheet. Descriptive and analytic work on the data was carried out, with modeling on 2 key performance indicators: chicken attrition rates and income levels from chicken production.

Results show that smallholder chicken raising in the uplands of Inopacan is typically a semi-scavenging system, with generally low productivity. Using epidemiological methods, 150 putative factors were examined for association with the 2 key performance indicators: overall chicken attrition (ATTRITION), and income from chicken production (INCOME). Of these factors, 13 and 29 variables were found to be associated $(\mathrm{P}<0.20)$, respectively, with ATTRITION and INCOME. Logistic regression analysis for ATTRITION revealed that feeding chickens while caged, giving rice as feed, and farmers' practice of treating sick chickens proved highly significant in the model. Likewise, for INCOME, analysis revealed that 5 factors were highly significant in the model: selling chickens owned for profit, commercial feed given as chicken feed, copramaking is a source of agricultural income, raiser is satisfied with the performance of his chicken flock, and amount of coconut given per flock per month. The implications of the results, and using the epidemiological approach in studying smallholder chicken productivity and health are discussed.

Keywords: Cross-sectional analysis, smallholder chicken systems, logistic regression model

Correspondence : E.B. Lañada Address: Department of Veterinary Medicine, Visayas State Unviersity, Visca, Baybay City, Leyte 6521-A, Philippines Email: eblanada@vsu.edu.ph DOI: $10.32945 /$ atr36s 19.2014 


\section{INTRODUCTION}

Smallholder chicken raising is very common in the Philippines, where it accounts for about $70 \%$ of the total poultry population (Ramlah, 2001). Majority (60\%) of the chickens raised by these smallholders are native Philippine breeds (Cocjin, et al., 2003).

Inherently, native Philippine breeds have lower productivity than exotic breeds forming the bulk of the commercial chicken industry. In addition, the use of these breeds for poultry production is further constrained by several factors such as high early chick attrition, low hatchability and poor growth rate. These constraints notwithstanding, the application of improved nutritional, management, financial and general technical inputs into the system generally results to improvement of productivity (Cocjin, et al., 2003). Improved productivity therefore translates to higher profitability and efficiency.

This work is the first part of the study on the effect of Newcastle Disease (ND) vaccination on the attrition rates of chickens raised by smallholder farmers in a marginal upland system. It seeks to establish baseline information on the current status of this system, and identify factors which may be manipulated further for improvement. Studies of this kind, which includes a wide range of indicators, has been carried out only recently in the Philippines (Lañada, et al., 2002; Lañada, et al., 2004). This paper therefore presents a descriptive and analytic report on smallholder chicken production in the marginal uplands of Inopacan, Leyte. Using epidemiological methods, opportunities and leverage points for the improvement of smallholder chicken productivity and profitability are identified in this report.

\section{MATERIALS AND METHODS}

\section{General study design}

This cross-sectional study formed the initial part of a larger project involving smallholder chicken raisers in the marginal upland barangays of Inopacan, Leyte, with the overall objective of reducing chicken attrition in smallholder systems by Newcastle Disease (ND) vaccination. This paper presents aspects of biological and economic characteristics relevant to smallholder chicken production, and rates of attrition in these animals in the municipality of Inopacan. For the purpose of this study, a smallholder 
Health and Productivity Of Chickens Raised By Smallholder Farmers

chicken raiser was defined as a small-scale chicken raiser who normally raises chickens for semi-subsistence purposes rather than on a full commercial scale. The farmer's chicken flock was the unit of interest in this study.

\section{Sampling and enrolment methodology}

Selection of barangays. The study was undertaken within the municipality of Inopacan, with four barangays selected for sampling. Criteria for selection included location (the barangay must be an upland barangay), access from Visayas State University (the study base), and willingness of municipal and barangay officials to cooperate for the duration of the study.

Enrolment of farmers. The reference population for this work included all farmers identified as suitable participants in a research study on reducing chicken attrition by Newcastle Disease (ND) vaccination. This study hypothesizes that reducing attrition by ND vaccination will improve their smallholder chicken production systems, and could be demonstrated by improved income from chickens. From each barangay, a list of households with smallholder chicken raisers was drawn up, from which a sample was selected. For this study, all chicken raisers within the identified barangays were considered eligible for enrolment, and approximately $10 \%$ of farmers from each barangay were then selected at random. The selected raisers were then subjected to questionnaire- and person-to-person interviews regarding their chicken production systems.

\section{Data collection, management, and analysis}

A questionnaire was administered to each chicken raiser during a single visit. The questionnaire was used to gather data about those variables that were considered to be related to the biology, productivity, profitability, and efficiency of chicken flocks. The questionnaire was constructed in English, and was subsequently translated into the local language of Cebuano. Relevant data on demographics, chicken management, chicken nutrition, chicken health and disease, and economics were recorded on the questionnaire at the time of the interviews. The information from the study was managed using Excel 2007, where data cleaning and preliminary descriptive analyses were carried out. Subsequently data were transferred to EpiInfo 7.0.9.7 (2012) 
where association tests, and univariable and multivariable logistic regression analyses were carried out.

\section{Descriptive and comparative analyses}

Standard methods were used to describe data relating to the biological and economic measures of chicken productivity, profit and efficiency. These included frequency distributions, means, medians and 95\% confidence intervals. Frequency distribution data were obtained from questions with multiple possible answers, to deal with overlapping combinations of activities of the chicken raisers. Comparisons between different categories of the indicator variables were carried out using oneway analysis of variance.

Most performance indicators relating to the profit and efficiency of chicken flocks were calculated on a monthly basis. These include attrition rates on three age groups (0-6 weeks, 6 weeks to 5 months, older than 5 months), hatchability, and reproductive rate. Partial budgeting techniques were used to measure income from chicken production.

\section{Measures of overall chicken attrition and income from chicken production}

Overall chicken attrition (losses from mortality, theft, predation, etc) was calculated using the formula: (total chickens lost in the past month/(total chickens lost in the past month + ending total population in the past month)) and income from chicken production was calculated using the formula: (value of chicken inventory in the past month + value of consumed chickens and eggs) - (total feed and other variable costs in the same period + value of lost chickens and eggs).

Two variables were created to serve as dependent variables for overall chicken attrition (ATTRITION) and income derived from chicken production (INCOME). These variables dichotomized values of overall chicken attrition into low (coded as 1 ) and high (coded as 0 ) categories, and income from chickens into high (coded as 1) and low (coded as 0 ), respectively. ATTRITION was created by calculating the median value of the variable overall chicken attrition, and values $>$ median coded as 0 and values $\leq$ median coded as 1 . INCOME was likewise created by calculating the median value for the variable on income derived from chicken production and coding values $>$ median as 1 and values corresponding to $\leq$ median as 0 . These created variables were used as dependent variables for 
Health and Productivity Of Chickens Raised By Smallholder Farmers

the univariable and multivariable statistical association tests on a variety of independent variables.

Factors putatively associated with the 2 dependent variables were derived from the questionnaire. A total of 150 factors were identified, covering demographics, chicken management, chicken nutrition, and chicken health and disease.

\section{Univariable analysis}

Univariate associations between independent and dependent variables were carried out using the chi-squared test for categorical variables and by either Student's t-test (for normally-distributed data) or Kruskal-Wallis test (for non-normally distributed data) for continuous variables. At this stage, variables with $\mathrm{P}<0.20$ were retained for inclusion into multivariate modeling.

\section{Multivariable analysis}

Variables with $\mathrm{P}<0.20$ were offered to unconditional logistic regression modeling (relative (multiplicative) risk type) using backward elimination procedure. At the first step, the independent variable with the least significant association with the dependent variable when the overall Pvalue was evaluated was deleted from the model. This step was again repeated, with the remaining variables regrouped, and the least significant variable again deleted. The same process continued until all the variables in the model remained highly significant $(\mathrm{P}<0.05)$ and the overall regression was also highly significant $(\mathrm{P}<0.05)$.

\section{RESULTS AND DISCUSSION}

\section{General description of the study areas}

The municipality of Inopacan is located on the western side of the island of Leyte, a part of the Visayan group of islands in central Philippines. It is bounded on the north, by Baybay City; on the south, by Hindang; on the west, by the Camotes Sea; and on the east, by the Municipalities of Mahaplag and Sogod. The Poblacion of Inopacan is located at the intersection of geographic coordinates $10^{\circ} 30^{\prime} 05^{\prime \prime}$ North latitude and 124 을 44' 20" East longitude (http://www.inopacan.gov.ph/about/geography/). 
The climate in the study areas is classified as tropical marine, with two major systems affecting the island, and the country as a whole: the northeast monsoon (November to April), and the southwest monsoon (May to October) (CIA World Factbook, 2003).

Four barangays are included in this survey: Linao, Mara-o, Guinsangaan, and Hinabay. Barangay Linao is traversed by the western coastal highway of Leyte, and consists mostly of upland areas, with part of the barangay considered as lowland due to its location near the coast. Barangays Mara-o, Guinsanga-an, and Hinabay are located in the uplands of Inopacan. Because of the relative distance and poor road conditions, the National Anti-Poverty Commission has classified Barangays Mara-o, Guinsanga-an, and Hinabay as "inaccessible" from the national highway (NAPC, 2013).

\section{Description of smallholder chicken raisers}

Two hundred and twelve smallholder households raising chickens were surveyed. Fifty-one (51) raisers were from barangay Linao, 105 from Mara-o, 23 from Guinsanga-an, and 33 from Hinabay. Majority (86.21\%) of these households sourced their income from agriculture, with nonlivestock crops providing the bulk (74.88\%) of agricultural income. Although the households mentioned that they get their agricultural income from a combination of crops, the most common sources identified were copra $(54.50 \%)$, rice $(37.44 \%)$, non-poultry livestock $(27.83 \%)$, and a variety of minor sources (corn, tuba, working as laborer, tenancy, and others).

Almost all (97.10\%) of the households considered the husband as the head of the family. Majority of the husbands (66.34\%) were able to reach only elementary-level education, with $28.22 \%$ reaching high school. Wives, however, were a little better educated, with $45.5 \%$ reaching high school, with only $50.00 \%$ staying at the elementary grades. The children, as a whole, were best in educational achievement, with $42.11 \%$ reaching high school, and $25.66 \%$ reaching college level education.

Regarding the ownership of the chicken enterprise, 33.49\% of the surveyed raisers said that the husband is the owner, with the wife only having $2.83 \%$. Majority of the respondents (60.66\%) said that the chicken enterprise belongs to the whole family. The husband is the person usually responsible for the daily upkeep of the chicken flock, according to $75.73 \%$ of respondents. All members of the family are responsible for this task at 
Health and Productivity Of Chickens Raised By Smallholder Farmers

the level of $16.02 \%$, and the wife is at $8.25 \%$.

General description of the smallholder chicken system

The chicken production system in the study areas is best described as a semi-scavenging system. All raisers have native Philippine breeds, or mixtures of Philippine breeds with exotic broiler breeds. Eighty-eight point sixty-three of raisers said they have free-range chickens, while $45.02 \%$ have caged chickens, and $18.10 \%$ have tethered chickens. Thirty-four point ninety-three percent of these raisers also have fighting cocks raised on farm. All raisers said that they raise chickens for food, and only $26.54 \%$ considered the chickens as an income source. Home breeding was practiced by $31.65 \%$ of raisers as the means of acquiring stock, while $24.17 \%$ and $25.12 \%$ cited gifts and purchases, respectively, as their means of obtaining chickens. Most raisers (83.89\%) said that their chickens just sleep on tree branches at night, and only $33.81 \%$ had elevated shelters.

Chickens produced by the raisers are mostly both for home consumption and sale ( $96.21 \%$ of raisers). Each household, on average, consumes 1.40 chickens per month. Only $24.17 \%$ raisers produce chickens purely for sale; $22.64 \%$ raise chickens for gambling (cockfights) or as a hobby. Eggs are mostly for hatching (mentioned by $98.10 \%$ of raisers); although $71.90 \%$ said that they eat some of the eggs produced by their flocks, though very rarely. Consumption of smallholder flock-produced eggs is 0.04 per month per household. Eggs produced are never sold.

\section{Chicken nutrition}

The feeding methods employed by the raisers are closely related to the methods of sheltering the chickens. These could either be by allowing pure scavenging methods (reported by $6.60 \%$ of raisers), scavenging with supplemental feeding (83.41\%), in-cage feeding (44.08\%), corralled feeding (5.66\%), and tethered feeding (11.79\%). Feed items given to chickens by raisers (either as main feed or supplement) are shown in Table 1.

\section{Chicken health}

Almost all (94.74\%) of chicken raisers had experienced disease in their chicken flocks. When asked about the diseases encountered they 
mentioned the following: "tukdaw" (known to 67.49\% of raisers), "sip-on" (43.78\%), "atay" (12.32\%), "ubo" (8.91\%), and other remaining diseases which included "pisokot", "poko", "halak", and "tuhib sa hinangkan". When asked what they do to sick chickens, they answered: medicate the sick chickens (63.59\%); bury the sick chickens (13.61\%); eat the sick chickens (2.36\%); throw them away (1.05\%); and, do nothing (32.98\%). Most raisers medicate their chickens with conventional treatments (41.55\%) obtained from agrivet stores (35.07\%).

Table. 1. Feed items given by smallholder chicken raisers (either as main feeds or supplements).

\begin{tabular}{lcc}
\hline & \% of raisers giving feed & $\begin{array}{c}\text { Average amount given } \\
\text { (g/month/farm) }\end{array}$ \\
\hline Rice & 63.81 & 5905.05 \\
Food scraps & 45.02 & 3787.92 \\
Commercial feed (crumble) & 37.14 & 5528.35 \\
Coconut (shredded) & 31.90 & 1938.11 \\
Commercial feed (mash) & 27.62 & 4554.34 \\
Corn & 20.00 & 2326.84 \\
Rice bran & 6.67 & 679.25 \\
\hline
\end{tabular}

Very few raisers (6.64\%) have knowledge about Newcastle Disease; the same is true with their knowledge on vaccinating chickens against it $(0.96 \%)$. Consequently, none of the chicken flocks raised by the surveyed farmers have been vaccinated against Newcastle Disease.

The signs of the disease "tukdaw" closely resemble the signs exhibited in Newcastle Disease (ND); thus when we described the signs of chickens affected by ND many farmers immediately pointed to "tukdaw", making it the most likely name for the disease in the local language. Many other chicken diseases (mostly bacterial) however may show similar signs.

\section{Reproductive performance of chicken flocks}

Flock sizes and other population parameters are found in Table 2 . Reproductive performance of the chicken flocks is found in Table 3. Because this study considered young chicks as part of the flock, unlike in some parts of Africa, where owners never include chicks when they refer to flock size, due to very high mortality in this age group (Permin and Bisgaard, 2001), the mean flock size of 16.33 (Table 2) is larger than the usual flock sizes seen in Africa (Kondombo, et al, 2003; Molla, 2010; 
Health and Productivity Of Chickens Raised By Smallholder Farmers

Meseret, et al., 2011). The mean clutch size of 10.22 is smaller than the 15 20 eggs per clutch reported in the central highlands of Ethiopia (Dessie and Ogle, 2001), but larger than the previous report by the author and his colleagues (Lañada, et al., 2004) in the lowland smallholder setting in the same area as this study. Hatchability of set eggs $(\mathrm{N}=202$; mean $=77.02 \%$; 95\% CI: 74.91\%-79.14\%) is slightly lower than many reports (Dessie and Ogle, 2001; G/Egziabher, 2007; Moges, et al., 2010). Chick survival at 2 months is higher than that reported in northwest Ethiopia (Moges, et al., 2010).

Table 2. Population characteristics of chickens raised by participating farmers in the marginal upland barangays of Inopacan, Leyte, Philippines.

\begin{tabular}{llllll}
\hline & $\mathrm{n}^{*}$ & Mean & Median & Range & 95\% CI \\
\hline 0-6 weeks & 211 & 7.60 & 6.5 & $0-50$ & $6.45-8.74$ \\
6 weeks to 5 months & 211 & 2.96 & 0 & $0-25$ & $2.30-3.62$ \\
Mature (>5 mo) & 212 & 5.82 & 5.5 & $0-24$ & $5.29-6.35$ \\
All ages (average) & 212 & 16.33 & 14 & $0-85$ & $14.81-17.84$ \\
\hline Mature Males & 211 & 2.73 & 2.5 & $0-20$ & $2.35-3.10$ \\
Hens (Layers and Non- & 211 & 3.12 & 3 & $0-10$ & $2.87-3.38$ \\
layers) & & & & & \\
Overall Male:Hen ratio & 205 & 0.98 & 0.67 & $0-6$ & $0.84-1.11$ \\
\hline
\end{tabular}

* number of chicken flocks for which data were available

Table 3. Monthly egg production and reproductive characteristics of the chickens raised by smallholders in the marginal upland barangays of Inopacan, Leyte, Philippines.

\begin{tabular}{llllll}
\hline & $\mathrm{n}^{*}$ & Mean & Median & Range & $95 \% \mathrm{CI}$ \\
\hline Clutch size & 2033 & 10.22 & 10 & $0-18$ & $9.88-10.56$ \\
Hatchability (\%) & 202 & 77.02 & 77.78 & $20-100$ & $74.91-79.14$ \\
Survival at 2 months (\%) & 201 & 70.93 & 71.43 & $7.69-100$ & $67.65-74.20$ \\
\hline
\end{tabular}

* number of chicken flocks for which data were available 


\section{Chicken attrition}

Attrition of the different age groups are shown in Table 4. The figures show that attrition is highest in the 0-6 weeks age group, which accounts for the most losses in the chicken flocks, very similar to results reported in Africa (Mtambo, 1999; Muhairwa, et al., 2001).The results of this study, however, showed lower attrition rates for young chicks, when compared to reports from southern Ethiopia (G/Egziabher, 2007) and northwest Ethiopia (Moges, et al, 2010). It is however, very similar to the findings of a study in Burkina Faso (Kondombo, et al., 2003).

Lañada, et al. (2004) reported that young chicks raised in upland areas averaged higher attrition rates (36.3\%) compared with chicks raised in lowland areas (17.24\%). Results of this present study are consistent with that finding; the barangays in the present study are upland areas of the municipality of Inopacan, with an average attrition rate of $30.61 \%$ in young chicks. The relative inaccessibility of the study areas may confound the results; the main coastal highway in the study areas are found in the lowland barangays of the municipality (not included in the present study) where the residents are relatively more affluent.

Because of the constraints imposed by the study design, we did not undertake actual visual observations and recording, and clinical and laboratory diagnoses of chicken attrition. Thus, opinions of chicken raisers as to the most common causes in the upland areas of Inopacan varied: theft (reported by $60.19 \%$ of farmers), diseases $(59.52 \%)$, birds of prey (25.94\%), cats and dogs (24.53\%), and snakes and rats (13.68\%). Further, the raisers mentioned that minor causes included other wild animals, accidents, lack of food, and others. These rates are comparable to rates reported elsewhere, where many reports state that the major causes of attrition were either disease or predation (Dessie and Ogle, 2001; Mapiye and Sibande, 2005; Biswas, et al., 2008).

Table 4. Attrition rates (\%) of chickens (categorized by age groups).

\begin{tabular}{llllll}
\hline Age group & $\mathrm{n}^{*}$ & Mean & Median & Range & 95\% CI \\
\hline 0-6 weeks & 172 & 30.61 & 16.67 & $0-100$ & $25.24-35.98$ \\
6 weeks to 5 months & 98 & 2.11 & 0 & $0-100$ & $-0.42-4.64$ \\
Mature (>5 mo) & 209 & 2.59 & 0 & $0-42.86$ & $1.46-3.73$ \\
All ages (average) & 211 & 13.88 & 7.69 & $0-83.33$ & $11.58-16.19$ \\
\hline
\end{tabular}

* number of chicken flocks for which data were available 
Health and Productivity Of Chickens Raised By Smallholder Farmers

\section{Income from chicken production}

If raisers are able to sell all their inventory for the past month, they would realize an average monthly income of PhP1194.11 $(\mathrm{n}=211$; median $=$ PhP1122.00; range $=$ PhP-1560.00 - PhP6400.00; 95\% CI \pm PhP160.08).

Factors associated with chicken attrition and income from chicken production

Table 5 shows the 14 significant variables $(p<0.2)$, out of the 150 putatively associated with ATTRITIION. There are 2 variables on demographics, 7 on chicken management, 3 on chicken nutrition, and 1 on chicken health and disease. Table 6 shows the unconditional logistic regression model for ATTRITION.

Table 5. Variables associated with chicken attrition levels (ATTRITION) in univariable analyses $(\mathrm{p}<0.20)$.

\begin{tabular}{lllll}
\hline VARIABLE & UNIT* & TEST & p-value \\
\hline Chicken management & & & \\
Farmers raise chickens for slaughter and/or consumption & 1,0 & $\chi^{2}$ & 0.14 \\
Chickens sleep in elevated areas & 1,0 & $\chi^{2}$ & 0.15 \\
Caging is method of keeping chickens & 1,0 & $\chi^{2}$ & 0.076 \\
Chicken nutrition & & & \\
& & t- & \\
& & & t & \\
Frequency of feeding per day & $\mathrm{N}$ & & $\mathrm{e}$ & 0.28 \\
& & & $\mathrm{~S}$ \\
& & & $\mathrm{t}$ \\
& $\mathrm{N}$ & $\mathrm{K}-\mathrm{W}$ & 0.1792 \\
Amount of rice bran given per flock per month & $\mathrm{N}$ & $\mathrm{K}-\mathrm{W}$ & 0.1948 \\
Amount of corn given per flock per month & 1,0 & $\chi^{2}$ & 0.028 \\
Chickens fed while caged & 1,0 & $\chi^{2}$ & 0.15 \\
Rice bran is given to chickens as feed & 1,0 & $\chi^{2}$ & 0.029 \\
Rice is given to chickens as feed & 1,0 & $\chi^{2}$ & 0.12 \\
Water for chickens obtained from bore holes & & & \\
Chicken health and disease & 1,0 & $\chi^{2}$ & 0.13 \\
Traditional methods used for treating chicken disease & 1,0 & $\chi^{2}$ & 0.16 \\
Raisers treat sick chickens & 1,0 & $\chi^{2}$ & 0.16 \\
"Tuhib sa hinangkan" has been observed to occur in chicken flock & 1,0 & $\chi^{2}$ & 0.19 \\
"Tukdaw" has been observed to occur in chicken flock & & &
\end{tabular}

* Codes shown for categorical variables 
Table 6. Flock-level logistic regression model for ATTRITION of 183 smallholder chicken flocks in Inopacan, Leyte.

\begin{tabular}{|c|c|c|c|c|c|}
\hline Variable & $b$ & $\mathrm{Se}(b)$ & $\begin{array}{c}\text { Adjusted } \\
\text { Odds } \\
\text { Ratio }\end{array}$ & $\begin{array}{l}95 \% \text { CI } \\
\text { (OR) }\end{array}$ & $P$ \\
\hline Chickens fed while caged & 0.6993 & 0.3523 & 2.0124 & $\begin{array}{r}1.0089 \\
4.0140\end{array}$ & 0.0471 \\
\hline $\begin{array}{l}\text { Rice is given to chickens } \\
\text { as feed }\end{array}$ & 0.7619 & 0.3704 & 0.4668 & $\begin{array}{r}0.2259 \\
0.9647\end{array}$ & 0.0397 \\
\hline $\begin{array}{l}\text { Raisers treat sick } \\
\text { chickens }\end{array}$ & 0.7633 & 0.3661 & 0.4661 & $\begin{array}{r}0.2275 \\
0.9552\end{array}$ & 0.0371 \\
\hline CONSTANT & 1.5336 & 0.4310 & $*$ & $*$ & 0.0004 \\
\hline
\end{tabular}

The logistic regression model for chicken attrition confirms what has already been demonstrated in an earlier study in the same area. Caging chickens (and feeding these while caged) is associated with low attrition (OR=2.0124; 95\% CI: 1.01, 4.01 P=0.0471). Lañada, et al. (2004) have shown that attrition of caged chickens was significantly lower than scavenging chickens. Probably because majority of chickens raised in the study areas are not caged or corralled $(88.63 \%$ of farmers reported that most of their chickens are either purely free-range scavengers or scavengers with supplementation), attrition is very high. Therefore, raising birds in cages would have a probability of having low attrition in the flock by 2.01 times. The fact that only a little more than half of the farmers reported the use of either cages or corrals in keeping chickens may explain why these farmers reported that the most common cause of chicken attrition is theft. Studies in Ethiopia (Dessie and Ogle, 2001), Zimbabwe (Mapiye and Sibande, 2005) and Bangladesh (Biswas, et al, 2008) showed similar results, but because most of the chicken flocks reported in these studies were caged, the role of disease and predation in attrition was more prominent.

Giving rice as feed (OR=0.4668; 95\% CI: 0.2259, 0.9647; $\mathrm{P}=0.0397$ ) decreases the odds of reduced attrition in smallholder chickens probably because farmers who use rice as feed usually give reduced amounts (or none at all) of commercial feeds. The farmers' practice of treating sick chickens (OR=0.4661; 95\% CI: 0.2275, 0.9552; $\mathrm{P}=0.0371$ ) also has the same effect; treating diseased chickens, although considered a sign of good attitude towards chicken health, usually are unsuccessful events because 
Health and Productivity Of Chickens Raised By Smallholder Farmers

of the farmers' lack of expertise in this area. Further, the absence of veterinarians in the study areas aggravates the situation.

Table 7 shows the 25 significant variables $(p<0.2)$ out of the 150 putatively associated with INCOME. There are 6 variables on demographics, 9 on chicken management, 9 on chicken nutrition, and 1 on chicken health and disease. Table 8 shows the unconditional logistic regression model for INCOME.

Table 7. Variables associated with levels of income obtained from chicken production (INCOME) in univariable analyses $(\mathrm{p}<0.20)$.

\begin{tabular}{|c|c|c|c|}
\hline VARIABLE DESCRIPTION & UNIT* & TEST & $\mathrm{p}$-value \\
\hline \multicolumn{4}{|l|}{ Demographics } \\
\hline Share of livestock in agricultural income & $\%$ & t-test & 0.101 \\
\hline $\begin{array}{l}\text { Copra making is a source of agricultural } \\
\text { income }\end{array}$ & 1,0 & $\chi^{2}$ & 0.14 \\
\hline $\begin{array}{l}\text { Working as hired laborer is a source of } \\
\text { agricultural income }\end{array}$ & 1,0 & $\chi^{2}$ & 0.19 \\
\hline $\begin{array}{l}\text { Other livestock raised is a source of } \\
\text { agricultural income }\end{array}$ & 1,0 & $\chi^{2}$ & 0.011 \\
\hline $\begin{array}{l}\text { Raiser is satisfied with performance of his } \\
\text { chicken flock }\end{array}$ & 1,0 & $\chi^{2}$ & 0.041 \\
\hline Chickens owned sold for profit & 1,0 & $\chi^{2}$ & 0.0034 \\
\hline \multicolumn{4}{|l|}{ Chicken management } \\
\hline Chickens sleep where they are tethered & 1,0 & $\chi^{2}$ & 0.17 \\
\hline Chicken cage cleaned at least once daily & 1,0 & $\chi^{2}$ & 0.067 \\
\hline Eggs produced are consumed at home & 1,0 & $\chi^{2}$ & 0.12 \\
\hline Eggs produced are hatched & 1,0 & $\chi^{2}$ & 0.13 \\
\hline Chickens fed while caged & 1,0 & $\chi^{2}$ & 0.15 \\
\hline Raisers practice homebreeding & 1,0 & $\chi^{2}$ & 0.069 \\
\hline Income is reason for raising chickens & 1,0 & $\chi^{2}$ & 0.017 \\
\hline Water given to chickens from other sources & 1,0 & $\chi^{2}$ & 0.051 \\
\hline Water given to chickens from open well & 1,0 & $\chi^{2}$ & 0.053 \\
\hline
\end{tabular}


Table 7 Continuation

\begin{tabular}{|c|c|c|c|}
\hline \multicolumn{4}{|l|}{ Chicken nutrition } \\
\hline Frequency of feeding chickens per day & $\mathrm{n}$ & t-test & 0.08 \\
\hline Amount of coconut given per flock per month & grams & $\mathrm{K}-\mathrm{W}$ & 0.0021 \\
\hline $\begin{array}{l}\text { Amount of commercial feeds given per flock } \\
\text { per month }\end{array}$ & grams & $\mathrm{K}-\mathrm{W}$ & 0.0028 \\
\hline Amount of corn given per flock per month & grams & $\mathrm{K}-\mathrm{W}$ & 0.054 \\
\hline Amount of crumble given per flock per month & grams & $\mathrm{K}-\mathrm{W}$ & 0.1478 \\
\hline Amount of rice given per flock per month & grams & $\mathrm{K}-\mathrm{W}$ & 0.0078 \\
\hline Coconut is given to chickens as feed & 1,0 & $\chi^{2}$ & 0.018 \\
\hline Commercial feed is given to chickens as feed & 1,0 & $\chi^{2}$ & 0.0033 \\
\hline Rice is given to chickens as feed & 1,0 & $\chi^{2}$ & 0.015 \\
\hline \multicolumn{4}{|l|}{ Chicken health and disease } \\
\hline Medications given by traditional healer & 1,0 & $\chi^{2}$ & 0.18 \\
\hline
\end{tabular}

* Codes shown for categorical variables

Table 8. Flock-level logistic regression model for INCOME of 172 smallholder chicken flocks in Inopacan, Leyte.

\begin{tabular}{|c|c|c|c|c|c|}
\hline Variable & $b$ & $S e(b)$ & $\begin{array}{c}\text { Adjusted } \\
\text { Odds } \\
\text { Ratio }\end{array}$ & $95 \%$ CI (OR) & $P$ \\
\hline $\begin{array}{l}\text { Copra making is a source of } \\
\text { agricultural income }\end{array}$ & 0.8785 & 0.3537 & 2.4074 & $1.2035,4.8155$ & 0.0130 \\
\hline $\begin{array}{l}\text { Commercial feed is given to } \\
\text { chickens as feed }\end{array}$ & 1.0157 & 0.3932 & 2.7614 & $1.2776,5.9684$ & 0.0098 \\
\hline $\begin{array}{l}\text { Raiser is satisfied with } \\
\text { performance of his chicken flock }\end{array}$ & 0.8039 & 0.3895 & 2.2343 & $1.0413,4.7939$ & 0.0390 \\
\hline Chickens owned sold for profit & 1.1145 & 0.4201 & 3.0480 & $1.3380,6.9433$ & 0.0080 \\
\hline $\begin{array}{l}\text { Amount of coconut given per flock } \\
\text { per month }\end{array}$ & -0.0001 & 0.0000 & 0.9999 & $0.9998,1.0000$ & 0.0036 \\
\hline CONSTANT & -1.4899 & 0.4199 & $*$ & $*$ & 0.0004 \\
\hline
\end{tabular}


Health and Productivity Of Chickens Raised By Smallholder Farmers

The model for INCOME shows that of the 5 variables in the model, selling chickens owned for profit had the highest odds ratio $(\mathrm{OR}=3.048$; 95\% CI: 1.338, 6.943; $\mathrm{P}=0.008)$, followed by: commercial feed given as chicken feed (OR=2.761; 95\% CI: 1.2776, 5.9684; $\mathrm{P}=0.0098)$, copramaking is a source of agricultural income (OR=2.4074; 95\% CI: 1.2035 , 4.8155; $\mathrm{P}=0.0130$ ), raiser is satisfied with the performance of his chicken flock (OR=2.2343; 95\% CI: 1.0413, 4.7939; $\mathrm{P}=0.0390$ ), and amount of coconut given per flock per month (OR=0.9999; 95\% CI: 0.9998, 1.0000; $\mathrm{P}=0.0036$ ). All these variables, except the last mentioned, had ORs $>1$, together with the lower limit of the $95 \% \mathrm{CI}$ at also $>1$. These indicate that these factors, based on data from the smallholder chicken raisers in the survey area, have major influence in explaining the productivity of chicken systems.

Having a purposive focus of selling chickens for profit has a direct influence on chicken productivity and may further encourage the raisers to invest more resources in chicken production. It is also a well known fact that nutritionally better feeds (either as main diets or supplements) produce more productive chickens (Henning, et al., 2009), which translates to higher profits. Being mostly involved in the production of coconuts (copra) enables these chicken farmers to provide readily available feeds to chickens, such as freshly-grated coconuts. However, the total amount of coconut given to chickens per is shown to be an activity that competes with the giving of other types of feeds to chickens. Giving more coconut as feed may reduce the amount of better feeds (e. g., commercial feeds) given to the chickens, resulting in a probability of increasing chicken productivity to $<1$.

The decision to use epidemiological methods in identifying constraints and opportunities for improving chicken production in the smallholder setting was encouraged by the results obtained by several studies using a similar approach (Lañada, et al., 1999; Lee, et al, 2005; More, et al. 1999; Lañada, et al., 2004), Further, the use of epidemiological techniques have been shown to have useful tools and techniques to describe and analyze the impact of multiple variables on animal productivity and health (Dewey, 2008).

Information obtained from the smallholder chicken farmers, however, raised considerable concerns regarding data quality, primarily because farmers do not keep adequate production and health records. As a result, information were mostly generated through farmer recall. Overcoming this concern has been addressed previously when considering smallholder livestock productivity (Lañada, et al., 1999; More, et al., 1999), In this 
present study, a similar approach was followed, wherein quantitative data used as outcome (dependent) variables (e. g., attrition and income from chicken production) were dichotomized into high and low categories. Despite resulting to reduced statistical power because of this dichotomization, we believe that this approach resulted in reducing misclassification errors due to inaccurate farmer recall of chicken production events.

It is possible that the low income from chicken production was due to farmers focusing on other enterprises and concentrating on other income generating activities such as crop farming or pig production. Since chicken production is mostly a low-input activity and generally not considered a main income source, reduction in production would not greatly affect overall farmer income. Farm households however still continue to maintain some semi-scavenging chickens, mainly for consumption.

The very low overall productivity of chicken systems as shown by this study is a direct result of many interrelated factors resulting mainly in high attrition in young chickens (which has a direct effect on inventory and value of production) and low nutritional, management, and health inputs into the system. One glaring omission from the system is vaccination against Newcastle Disease. It has been established that vaccination against $\mathrm{ND}$, both in commercial and smallholder scavenging systems, results in decreased chicken mortality (Henning, et al., 2008; Rahsid, et al., 2012). Although this factor was not part of the analytic modeling for improved production and survival of chickens in the uplands of Inopacan (due to absence of data on ND vaccination), it may yet prove to be one of the key factors for improving and sustaining the smallholder chicken systems in the study site.

\section{REFERENCES}

BISWAS, P. K., UDDIN, G. M. N., BARUA, H., ROY, K., BISWAS, D.,AHAD, A., and DEBNATH, N. C. (2008). Survivability and causes of loss of broody-hen chicks on smallholder households in Bangladesh. Prev. Vet. Med. 83: 260-271.

CIA WORLD FACTBOOK. (2003).

COCJIN, B. B., ROXAS, G. F. A., CASIPLE, C. G., and ARENGA, R. L. (2003). Conservation, improvement, and utilization of the Darag Philippine 
Health and Productivity Of Chickens Raised By Smallholder Farmers

native chicken. $1^{\text {st }}$ International Farmer-to-farmer Forum. Leyte Livestock Improvement Project, Leyte State University, Visca, Baybay, Leyte, October 21-23, 2003.

DESSIE, T., and OGLE, B. (2001). Village Poultry Production Systems in the Central Highlands of Ethiopia. Trop. Anim. Hlth. Prod.33(6): 521-537.

DEWEY, C. (2008). The use of epidemiology to enhance animal production research. Prev. Vet. Med. 86: 244-249.

G/EGZIABHER, M. M. (2007). Characterization of smallholder poultry production and marketing system of Dale, Wonsho and Loka Abaya Weredas of Southern Ethiopia. MSc thesis (Animal Production). 95p. Awassa (Ethiopia): Hawassa University.

HALIMA, H., NESER, F. W. C., VAN MARLE-KOSTER, E., and DE KOCK, A. (2007). Village-based indigenous chicken production system in northwest Ethiopia. Trop. Anim. Hlth. Prod. 39(3): 189-197.

HENNING, J., MORTON, J., HLA, T., and MEERS, J. (2008). Mortality rates adjusted for unobserved deaths and associations with Newcastle disease virus serology among unvaccinated village chickens in Myanmar. Prev. Vet. Med. 85: 241-252.

HENNING, J.,_MORTON, J.,PYM, R., HLA, T., and MEERS, J. (2009). Evaluation of strategies to improve village chicken productioncontrolled field trials to assess effects of Newcastle disease vaccination and altered chick rearing in Myanmar. Prev. Vet. Med. 90: 17-30.

KONDOMBO, S. R., NIANOGO, A. J., KWAKEL, R. P., UDO, H. M. Y., and SLINGERLAND, M. (2003). Comparative Analysis of Village Chicken Production in Two Farming Systems in Burkina Faso. Trop. Anim. Hlth. Prod.35(6): 563-574.

LAÑADA, E. B., LEE, J. A., MORE, S. J., TAVEROS, A. A., and COTIW-AN, B. (1999). The reproductive performance of sows raised by smallholder farmers in the Philippines. Prev. Vet. Med. 41:171-186. 
LAÑADA, E. B., MORBOS, E. Y., GABUNADA, F. M., PIAMONTE, E. R., and BESTIL, L. C. (2002). A descriptive study on smallholder chicken production in western Leyte, Philippines. Proc. $7^{\text {th }}$ WPSA Asian Pacific Federation Conference, October 6-10, 2002, Gold Coast, Queensland, Australia.

LAÑADA, E. B., ROLA-RUBZEN, M. F., MORBOS, E. Y., LLANOS, C. P., ESPINOSA, E. A., and PYM, R. A. E. (2004). A longitudinal analysis of chicken production systems of smallholder farmers in Leyte, Philippines. (PDF File 1737 in Proceedings CD). Proc. XXII World's Poultry Congress, Istanbul, Turkey, June 8-13, 2004.

LEE, J. A., LAÑADA, E. B., MORE, S. J., COTIW-AN, B. S., and TAVEROS, A. A. (2005). A longitudinal study of growing pigs raised by smallholder farmers in the Philippines. Prev. Vet. Med. 70: (1-2), 75-93.

MAPIYE, C., and SIBANDA, S. (2005). Constraints and opportunities of village chicken production systems in the smallholder sector of Rushinga district of Zimbabwe. Livestock Research for Rural Development 17 (10): 2005.

MESERET, M., SOLOMON, D., and TADELLE, D. (2011). Marketing System, Socio Economic Role and Intra Household Dynamics of Indigenous Chicken in Gomma Wereda, Jimma Zone, Ethiopia. Livestock Research for Rural Development 23 (6): 2011.

MOGES, F., MELLESSE, A., and DESSIE, T. (2010). Assessment of village chicken production system and evaluation of the productive and reproductive performance of local chicken ecotype in Bure district, Northwest Ethiopia. Afr. J. Agric. Res. 5(13): 1739-1748.

MOLLA, M. 2010. Characterization of village chicken production and marketing system in Gomma Wereda, Jimma Zone, Ethiopia. MSc thesis in Animal Sciences (Animal Production. 92p. Jimma (Ethiopia): Jimma University.

MORE, S. J., LEE, J. A., LAÑADA, E. B., TAVEROS, A. A., and COTIW-AN, B. (1999). Weight-for-age of growing pigs raised by smallholder farmers in the Philippines. Prev. Vet. Med. 41:151-169. 
Health and Productivity Of Chickens Raised By Smallholder Farmers

MTAMBO, M. M. A. (1999). Improving the health and productivity of the rural chickens in Africa: Report of Phase 1 of an Enreca sponsored project.http://www.husdyr.kvl.dk/htm/php/tune99/11-Mtambo.htm.

MUHAIRWA, A. P., YONGOLO, M. G. S., BUZA, J. J., JULU, B., MDEGELA, R. H., MTAMBO, M. M. A., and MINGA, U. M. (2001). Disease trends and prospects of reducing losses in free ranging village chickens in Tanzania. Proc. 10th Conf. Assoc. Inst. Trop. Vet. Med. Copenhagen, Denmark.

NAPC (2013). http://maps.napc.gov.ph/opendata/index.php /datasets/raw-data/finish/188-poor-households-and-access-tohighways/1217-inopacan-0. National Anti-Poverty Commission.

RAMLAH, A. H. (2001). Production aspects of village chicken in the SouthEast Asian Region. The First INFPD/FAO Electronic Conference on Family Poultry.

RASHID, M. H., XUE, C., ISLAM, M. R., ISLAM, M. T., and CAO, Y. (2013). A longitudinal study on the incidence of mortality of infectious diseases of commercial layer birds in Bangladesh. Prev. Vet. Med. 109 (3-4): 354358. 